\title{
PENGEMBANGAN BUKU AJAR PRAGMATIK EDUKASIONAL TERINTEGRASI KONTEKS INTRALINGUAL DAN BUDAYA PADA MAHASISWA PROGRAM MAGISTER PBSI UNIVERSITAS SANATA DHARMA YOGYAKARTA
}

\author{
Odilia Jayanti Mahu \\ Sekolah Tinggi Ilmu Ekonomi Karya Ruteng \\ Jl. Yos Sudarso No. 1 Ruteng, Kab. Kec. Ruteng - Kab. Manggarai, Indonesia \\ Pos-el : mahuyanti757@gmail.com
}

\begin{abstract}
The main objectives can be detailed as follows: 1) describe the needs needed by the students of the MPBSI, FKIP, University of Sanata Dharma in terms of learning the Pragmatic Education course. 2) describe the development of Educational Pragmatics textbooks integrated intralingual and cultural context in students of the MPBSI Program, FKIP, University of Sanata Dharma in terms of learning educational pragmatic subjects. This research uses research and development (RED) methods. The results of the development show that textbooks are suitable for use in the learning process. This can be concluded from the results of expert validation, the assessment of lecturers and the results of field trials to students of the Indonesian Language and Literature Education Study Program, University of Sanata Dharma, Yogyakarta.
\end{abstract}

Keywords: research and development, intralingual context, cultural context, textbooks.

\begin{abstract}
ABSTRAK
Tujuan penulisan artikel ini yaitu 1) mendeskripsikan kebutuhankebutuhan yang diperlukan mahasiswa Program MPBSI, FKIP, Universsitas Sanata Dharma dalam hal pembelajaran mata kuliah Pragmatik Edukasional. 2) Mendeskripsikan pengembangan buku ajar Pragmatik Edukasional terintegrasi konteks intralingual dan budaya pada mahasiswa Program MPBSI, FKIP, Universsitas Sanata Dharma dalam hal pembelajaran mata kuliah pragmatik edukasional. Penelitian ini memakai metode penelitian dan pengembangan (R\&D). Hasil pengembangan menunjukkan bahwa buku ajar layak digunakan dalam proses pembelajaran. Hal ini dapat
\end{abstract} (68-80) 
disimpulkan dari hasil validasi ahli, penilaian dosen dan hasil uji coba lapangan kepada mahasiswa Program Studi Pendidikan Bahasa dan Sastra Indonesia Universitas Sanata Dharma Yogyakarta.

Kata Kunci: penelitian dan pengembangan, konteks intralingual, konteks budaya, buku ajar.

\section{PENDAHULUAN}

Kegiatan berbahasa dalam kehidupan sehari-hari tidak akan terlepas dari penggunaan unsur intralingual. Unsur intralingual yang dimaksud adalah unsur kata, frasa, klausa dan kalimat. Penggunaan unsur intralingual ini bukan saja ditemukan pada kegiatan berbahasa lisan tetapi juga nampak pada penggunaan bahasa tulis. Keberadaan unsur atau konteks intralingual dalam sebuah wacana sangat membantu untuk memahami makna dan maksud dibalik suatu kalimat yang dituliskan atau diucapkan. Penggunaan kata, frasa, klausa, kalimat dalam kegiatan berbahasa biasa juga disebut penggunaan unsur koteks. Kridalaksana (2011), menjelaskan bahwa koteks adalah kalimat atau unsur kalimat yang mendahului dan atau mengikuti sebuah unsur lain dalam wacana. Koteks adalah teks yang mendampingin teks lain dan kedua teks tersebut saling keterkaitan, dan keberadaan teks yang didampingi itu bisa terletak di depan atau di belakang. Berdasarkan kamus linguistik dalam Sriyanto (2016), menjelaskan pengertian koteks sebagai kalimat atau unsur-unsur yang mendahului atau mengikuti sebuah unsur lain dalam wacana. Dalam artikel yang ditulis oleh Izhar (2016), menjelaskan koteks hubungan antarkalimat yang saling berkait dan saling menerangkan. Dari beberapa pendapat ahli di atas dapat disimpulkan bahwa konteks intralingual atau unsur intralingual adalah satuan linguistik yang digunakan oleh penutur atau penulis untuk mengekspresikan sebuah gagasan. Namun, ada kala penggunaan unsur intalingual itu terjadi kesalahan dalam pemakaiannya. Penggunaan kata yang salah ketika melakukan kegiatan berbahasa bisa disebabkan oleh minimnya pemahaman seorang terhadap konteks intralingual kebahasaan. Penyebab kedua, karena perbedaan penggunaan bahasa di kalangan masyarakat. Masyarakat yang menggunakan bahasa terdiri dari dua golongan yaitu golongan tua dan golongan muda. Golongan anak muda menggunakan bahasa cendrung dinamis, sedangkan bahasa yang sering digunakan oleh para orang tua cendrung kakuh. Biasanya penggunaan bahasa anak muda inilah yang sering terjadi kesalahan. Kemunculan sosial media menjadi salah satu pemicu utama penggunaan bahasa di kalangan anak muda sangat cepat berkembang. Perkembangan perubahan bahasa ini sedikitnya merusak tatanan penggunaan bahasa Indonesia yang baik dan benar. Hal ini bisa dibuktikan pada hasil penelitian yang dilakukan pada Mahasiswa Program Magister Pendidikan Bahasa dan Sastra Indonesia Universitas Sanata Dharma. Berdasarkan hasil pengumpulan informasi yang dilakukan pada mahasiswa Program Magister Pendidikan Bahasa dan Sastra Indonesia ternyata cukup banyak yang belum memahami apa itu konteks intralingual 
baik pemahaman secara teoritis maupun penggunaannya dalam kehidupan sehari-hari. Mahasiswa mungkin saja menggunakan bahasa setiap hari, namun tak menyadari bahwa penggunaan bahasa tersebut merupakan salah satu contoh penerapan unsur intralingual. Hal ini dapat dibuktikan dengan hasil isian kuesioner "pernyataan 16", pada pernyataan ini sebanyak 66\% mahasiswa yang menyatakan kurang memahami mengenai konteks intralingual. Fakta tersebut tentu saja bisa mempengaruhi terhadap proses pembelajaran pragmatik edukasional. Di dalam proses pembelajaran pastinya akan selalu menuntut mahasiswa agar cakap menggunakan bahasa, namun apa jadinya jika sebagian besar mahasiswa tidak memahami tentang konteks intralingual dalam kebahasaan?. Untuk menemukan informasi yang lebih dalam selain pembagian kuesioner, peneliti melakukan kegiatan observasi dalam pembelajaran pragmatik edukasional.

Hasil observasi yang didapatkan yaitu beruapa tuturan mahasiswa yang menandakan bahwa mereka ternyata masih keliru menggunakan satuan lingual. Hal ini dibuktikan dengan tuturan berikut "saya memberikan contoh seperti misalnya." Penggunaan tuturan seperti yang ada dalam tanda kutip merupakan salah satu ciri kalimat yang tidak efektif. Kata "contoh" memiliki makna yang sama denga kata "seperti" juga memiliki makna yang sama pada kata "misalnya", ketiga kata itu dapat dimaknai sebagai sesuatu yang dapat diandaikan dengan bermaksud mempermudah pemahamn seseorang terhadap sesuatu yang sedang kita jelaskan. Penggunaan sinomim yang sama dalam satu kalimat menimbulkan pemborosan kata dan mengakibatkan ketidakefektifan kalimat. Sejalan dengan yang disampaikan Ariffin (2009), bahwa salah satu ciri kalimat efektif ialah kehematan kata yaitu hemat dalam menggunakan kata, frasa atau bentuk lain dan tidak menggunakan apapun yang dianggap tidak perlu.

Pada pembelajaran pragmatik edukasional bukan saja satuan lingual yang perlu diajarkan kepada maahasiswa. Ada unsur lain di luar bahasa yaitu konteks. Dalam hal ini peneliti akan lebih spesifik berbicara mengenai konteks budaya. Konteks budaya merupakan konteks di luar teks yang perlu diperhatikan pada saat berkomunikasi. Ketika berkomunikasi tentunya membutuhkan kedua partisipan, budaya dari kudua partisipan tersebut menentukan apa yang boleh dilakukan oleh partisipan tertentu dengan cara tertentu pula. Mahasiswa MPBSI di Universitas Sanata Dharma terdiri dari berbagai latar budaya. Perbedaan budaya ini akan turut memengaruhi cara mereka berinteraksi satu sama lain dan bisa saja menimbulkan kesalahan dalam menanggapi tuturan. Oleh karena itu, agar komunikasi di dalam aktivitas pembelajaran berjalan harmonis maka perlu diterapkan pembelajaran dengan mengintegrasikan konteks budaya.

Berdasarkan hasil penelitian menunjukkan satu fakta bahwa mahasiswa MPBSI sangat setuju jika pembelajaran pragmatik edukasional diintegrasikan dengan konteks budaya. 
Hal ini dapat diketahui melalui hasil isian kuesioner pada "pernyataan 31" menunjukkan sebanyak $100 \%$ mahasiswa mengatakan dengan mengintegrasikan konteks budaya di dalam pembelajaran pragmatik edukasional akan membantu memahami tuturan dengan teman yang berbeda latar budaya.

Dari penelitian mengenai konteks intralinguaal dan budaya pada mahasiswa MPBSI, peneliti juga menemukan fakta bahwa ternyata mahasiswa MPBSI sebagain besar belum memiliki buku ajar yang di dalamnya berbicara mengenai konteks intralingual dan budaya. Hal ini dapat di ketahui dari hasil isisan kuesioner "pernyataan 37" hanya 31\% mahasiswa yang pernah membaca buku atau bahan ajar mengenai konteks intralingual dan pada "pernyataan 38" hanya 37\% mahasiswa yang pernah membaca buku atau bahan ajar yang membahas onteks intralingual.

Berdasarkan fakta dan beberapa data yang telah ditemukan peneliti di lapangan, ternyata mahasiswa MPBSI membutuhkan ketersedian referensi sebagai sumber acuan untuk mempelajari konteks intralingual dan budaya. Oleh karena itu, peneliti akan mengembangkan sebuah buku ajar pragmatik edukasional yang didalamnya terdapat materi mengenai konteks intralingual dan budaya.

\section{METODE PENELITIAN}

Dalam penelitian ini, peneliti mengangkat langkah-langkah penelitian dan pengembangan Borg dan Gall (Tegeh, dkk, 2014: 7). Adapun langkahlangkah penelitian yang diangkat oleh Borg and Gall yaitu memiliki sepuluh langkah yaitu : 1) Potensi masalah 2) Mengumpulkan informasi 3) Desain Produk 4) Validasi desain 5) Perbaikan desain 6) Uji coba produk 7) Revisi produk 8) Uji coba produk 9) Revisi Produk 10) Pembuatan Produk masal.

Berdasarkan pertimbangan peneliti yang memiliki keterbatasan waktu untuk mengembangkan produk melalui sepuluh langkah di atas, maka prosedur pengembangan yang dilakukan peneliti hanya menggunkan 8 langkah. Penjabaran 8 langkah prosedur pengembangan produk sebagai berikut: Melakukan pengumpulan informasi dengan cara analisis kebutuhan pada mahasiswa MPBSI yang menjadi pengguna produk. Analisis kebutuhan ini dilakukan agar produk yang dihasilkan sesuai dengan kebutuhan pengguna di lapangan. Analisis kebutuhan ini menggunakan empat cara yaitu pembagian kuesioner, pelaksanaan observasi, menganalisis dokumen,pelaksanaan tes. Tahap kedua perencanaan, setelah mendapatkan semua informasi pada tahap pertma di atas maka, peneliti akan mulai menrencanakan bentuk produk buku ajar yang nantinya akan dibuat oleh peneliti. Buku ajar yang dihasilkan tentu saja tetap berlandaskan dari Rencana.

Pembelajaran Semester (RPS). Oleh karena itu, pada tahap perencanaan ini peneliti momodifikasi RPS yang telah dibuat oleh dosen pengampu mata kuliah pragmatik edukasional untuk menentukan ruang lingkup materi yang akan dikembangkan dalam buku ajar. Modifikasi RPS dengan cara menambahkan materi yang

Odilia Jayanti Mahu, Variasi Bahasa.............. (68-80) 
dikembangkan oleh peneliti dalam buku ajar, mengubah beberapa capaian akhir dan metode pembelajaran yang digunakan dalam proses perkuliahan, menambah kegiatan pembelajaran, menambah rubrik penilaian yang dikembangkan oleh peneliti ke dalam RPS terdahulu yang sudah dibuat oleh dosen mata kuliah pragmatik edukasional.

Tahap keempat yaitu validasi produk, validasi produk dilakukan oleh ahli pragmatik dengan tujuan untuk memastikan buku ajar yang telah dibuat oleh peneliti memenuhi kevaliditasan baik dari segi aspek materi, aspek bahasa maupun aspek tampilan. Tahap kelima revisi produk, apabila hasil validasi dari ahli masih terdapat kekurangan pada buku ajar yang telah dibuat maka peneliti akan melakukan proses revisi produk. Proses revisi tersebut tentu saja berpedoman dari dari masukan dan saran yang dinilai oleh ahli. Tahap keenam uji coba produk, uji coba produk pada pengguna atau sasaran yang akan menggunakan produk buku ajar dengan skala terbatas.

Tahap ketujuh revisi produk, tahap ini merupakan tahap terakhir yang dilakukan peneliti. Apabila pada saat menguji coba produk, dosen dan mahasiswa menilai bahwa buku ajar masih terdapat kekurangan baik dari segi materi, kebahasaan maupun tampilan maka peneliti akan melakukan revisi terakhir guna menghasilkan buku ajar yang benar-benar sesuai dengan harapan pengguna. Tahap kedelapan, produk akhir, pada tahap ini peneliti menghasilkan buku ajar yang siap digunakan oleh pengguna. Buku ajar yang telah layak digunakan dan sudah dinilai oleh ahli,dosen pengampuh mata kuliah,dan penilaian dari mahasiswa.

Sumber data dalam penelitian berupa data penelitian dan data pengembangan yang didapat dari mahasiswa MPBSI dan dosen pengampuh mata kuliah pragmatik edukasional serta penilaian ahli pragmatik. Dari sumber data di atas dilakukan pengumpulan data dengan cara pembagian kuesioner, melakukan observasi, telaah dokumen (RPS) mata kuliah pragmatik edukasional serta melaksanakan tes. Selanjutnya data pengembangan didapatkan melalui validasi produk oleh ahli, penilaian produk oleh dosen pengampuh mata kuliah pragmatik edukasional dan hasil uji coba lapangan kepada mahasiswa MPBSI. Adapun aspek yang dinilai oleh ketiga sumber data di atas yaitu : aspek bahan ajar, aspek materi dan aspek bahasa di dalam buku ajar.

Teknik pengumpulan data yang dilakukan oleh peneliti yaitu menggunakan dua cara yaitu pengumpulan data penelitian dan pengumpulan data pengembangan. Pengumpulan data penelitian dengan cara menyebarkan kuesioner, melakukan obervasi, telaah dokumen (RPS) mata kuliah pragmatik edukasional dan melaksanakan tes. Sedangkan pada tahap pengembangan produk peneliti mengumpulkan data melalui validasi produk, penilaian produk oleh dosen pengampuh mata kuliah pragmatik edukasional dan mahasiswa.

Instrumen yang digunakan pada penelitian yaitu lembar kuesioner, 
lembar observasi pada mata kuliah pragmatik edukasional, lembar dokumen (RPS) mata kuliah pragmatik edukasional serta lembar soal-soal tes. Selanjutnya, pada tahap pengembangan instrumen yang digunakan, yaitu lembar kuesioner validasi produk oleh ahli pragmatik, lembar kuesioner penilaian produk oleh dosen pengampuh mata kuliah pragmatik edukasional dan mahasiswa. Adapun aspek yang dinilai yaitu aspek bahan ajar, materi dan bahasa. Teknik analisis data dalam penelitian menggunakan dua cara yaitu, analisis data menggunakan pendekatan kuantitatif dan analisis data menggunakan pendekatan kulitatif. Data-data yang dianalisis menggunakan pendekatan kualitatif adalah 1) hasil oberservasi, 2) hasil telaah dokumen. Sedangkan analisis menggunakan pendekatan kuantitatif adalah 1) hasil isian kuesioner, 2) hasil tes, 3) data validasi produk ahli 4) data hasil penilaian produk dosen mata kuliah dan 5) data hasil uji coba lapangan pada mahasiswa.

Data kualitatif dianalisis menggunakan tiga tahap. Miles and Huberman dalam Sugiyono (2017), menjelaskan ada tiga tahap analisis data kualitatif yaitu redukasi data, penyajian data, verifikasi data. Pada tahap merudukasi data peneliti merangkum semua data dari kuesioner, kegiatan observasi, analisis dokumen (RPS) dan pelaksaan tes, setelah itu memilih data yang berkaitan dengan pengintegrasian konteks intralingual dan budaya. Dengan demikian dari semua data yang terkumpulkan peneliti dapat memfokuskan pada subjek yang sedang diteliti. Tahap penyajian data, pada tahap ini peneliti mengelompokkan data pada setiap variabel dalam bentuk tabulasi data hal ini dilakukan untuk memudahkan peneliti dalam memahami data dan selanjutnya diinterpretasikan. Tahap ketiga yaitu verifikasi data, pada tahap ini peneliti akan menyimpulkan datadata yang sudah terkumpulkan.

Data kuantitatif berupa hasil isian kuesioner analisis kebutuhan dan skor tes. Adapun kuesioner tersebut dianalisis menggunakan skala Guttman. Isian kuesioner tersebut kemudian dibuat dalam bentuk tabulasi data dari pernyataan 1 sampai pernyataan 40 setelah itu akan dideskripsikan menggunakan statistik deskriptif dengar cara mencari hasil rata-rata. Untuk Jawaban "Ya" akan diberi skor 1 dan jawaban "Tidak" diberi skor 0. Penggunaan skala Guttman untuk mendapatkan jawaban tegas dan konsisten dari responden terhadap topik penelitian yang sedang diteliti. Selanjutnya hasil tes dianalisis menggunakan rumus skor sistem tanpa denda, yang dihitung hanya jawaban yang benar saja.

\section{Tabel 1.1 Skor dan Kategori skala Guttman}

\begin{tabular}{|c|c|}
\hline Skor & Kategori \\
\hline $\mathbf{1}$ & Ya \\
\hline $\mathbf{0}$ & Tidak \\
\hline
\end{tabular}

Berikutnya data kuantitatif berupa skor validasi oleh dosen ahli Pragmatik, dosen pengampuh mata Odilia Jayanti Mahu, Variasi Bahasa. $(68-80)$ 
kuliah dan mahasiswa sebagai pengguna produk yang akan menggunakan analisis statistik dekriptif. Pada tahap ini peneliti menerapkan skala Likert dengan model 4 kategori yaitu kategori jawaban sangat baik $=4$, jawaban baik $=3$, jawaban tidak baik $=$ 2 , dan jawaban sangat tidak baik $=1$. Widoyoko (2015), menjelaskan penggunaan skala 4 mimiliki variabilitas respon lebih baik, dan tidak ada peluang untuk responden untuk bersikap netral sehingga memungkiankan responden untuk menentukan sikap terhadap pernyataan yang disampaikan peneliti.

\section{Skor dan Kategori skala 4}

Skor

4 : Sangat Baik

3 : Baik

2 : Tidak Baik

1 : Sangat Tidak Baik

Untuk mentukan jarak interval

mengenai jenjang sikap responden mulai dari kategori sangat baik, baik, tidak

baik sampai sangat tidak baik

menggunakan rumus:

Skor tertinggi : 4

Skor terendah : 1

Jumlah kelas : 4

Jarak Interval : Skor tertinggi-Skor

terendah : 4

Jarak Interval : 4-3: $1=0,75$

Dalam penelitian ini peneliti mengangkat langkah-langkah penelitian dan pengembangan Borg dan Gall (Tegeh, dkk, 2014: 7) Adapun langkahlangkah penelitian yang diangkat oleh Borg and Gall yaitu memiliki sepuluh langkah yaitu : 1) Potensi masalah 2) Mengumpulkan informasi 3) Desain Produk 4) Validasi desain 5) Perbaikan desain 6) Uji coba produk 7) Revisi produk 8) Uji coba produk 9) Revisi Produk 10) Pembuatan Produk masal.

Berdasarkan pertimbangan peneliti yang memiliki keterbatasan waktu untuk mengembangkan produk melalui sepuluh langkah di atas, maka prosedur pengembangan yang dilakukan peneliti hanya menggunkan 8 langkah.

\section{HASIL DAN PEMBAHASAN Hasil Penelitian}

Hasil pengembangan buku ajar daalam penelitian ini menunjukkkan layak digunakan pada mahasiswa Program Magister Pendidikan bahasa dan sastra Indonesia dalam proses pembelajaran pragmatik edukasional. Hal ini dapat disimpulkan dari hasil validasi ahli, hasil penilaian dosen mata kuliah pragmatik edukasional, dan hasil uji coba lapangan kepada mahasiswa Program Magister Pendidikan Bahasa dan Sastra Indonesia.

Berdasarkan hasil validasi ahli terhadap aspek materi mencapai skor 3,20 dengan kategori "baik", aspek kebahasaan mencapai skor 4 dengan kategori "sangat baik", aspek tampilan mencapai skor 3,6 dengan kategori "baik", secara keseluruhan mendapatkan skor rata-rata 3,6 dengan kategori "baik".

Selanjutnya berdasarkan hasil penilaian dosen mata kuliah pragmatik edukasional. penilaian pada aspek materi mendapatkan skor 4 dengan katgori "sangat baik", penilaian aspek kebahasaan mendapatkan skor 4 dengan kategori "sangat baik" dan pada penilaian aspek tampilan mendapatkan skor 3,8 dengan kategori "sangat baik". Jumlah keseluruhan 
kulitas buku ajar yang dinilai oleh dosen mata kuliah adalah 3,93 dengan kategori "sangat baik".

Berdasarkan hasil uji coba lapangan, penilaian mahasiswa terhadap kualitas buku ajar aspek materi mendapatkan skor 3,55 dengan kategori "sangat baik ", aspek kebahasaan mendapatkan skor 3,56 dengan kategori "sangat baik", aspek tampilan mendapatkan skor 3,45 dengan kategori "sangat baik". Rangkuman skor rata-rata penilaian kulitas buku ajar dari mahasiswa adalah 3,56 dengan kategori "sangat baik".

Berdasarkan uji efektivitas, dapat disimpulkan bahwa buku ajar yang dikembangkan oleh peneliti dapat digunakan mahasiswa dalam proses pembelajaran pragmatik edukasional, hal ini dapat dilihat dari hasil pengerjaan tugas dari mahasiswa yang sudah menjelaskan secara rinci dan lengkap mengenai pengertian konteks intralingual, jenis-jenis unsur konteks intralingual atau koteks dalam wacana, hubungan koteks dan konteks, peran kohesi dan koherensi sebagai penanda unsur intralingual dalam sebuah wacana. Hal yang sama pada tugas tentang konteks budaya, hasil pengerjaan mahasiswa juga menunjukkan bahwa buku ajar sangat efektif untuk digunakana. Hal ini dapat dibuktikan melaui hasil jawaban mahasiswa yang menjelaskan secara lengkap dan terperinci pengertian dari konteks budaya, konteks budaya dalam kaitannya dengan kehidupan manusia dan relevansinya dengan pembelajaran, peran konteks budaya dalam pembela jaran pragmatik edukasional, maanfaat penerapan konteks budaya dalam pembelajaran.

\section{PEMBAHASAN}

Tahap awal yang dilakukan oleh peneliti sebelum mengembangkan produk adalah melakukan pengumpulan informasi. Pada saat pengumpulan informasi ini, peneliti menemukan sebagian besar mahasiswa program MPBSI belum paham mengenai konteks intralingual dan budaya, baik secara teoritis mapun penggunaannya dalam kehidupan sehari-hari khususnya dalam kegiatan pembelajaran pragmatik edukasional. Hal ini dibuktikan dengan hasil persentase jawaban pada kuesioner pernyataan 11 yang mencapai 95\% mahasiswa ternyata mengalami kesulitan dalam memilih kata-kata tertentu untuk menyampaikan gagasan. Dari fakta inilah peneliti menyimpulkan bahwa penggunan konteks intralingual dalam kegiatan berbahasa pada mahasiswa MPBSI bisa dikatakan masih rendah. Kesulitan dalam memilih kata-kata tertentu saat berbicara akan mengakibatkan tidak akuratnya informasi yang disampaikan. Sejalan dengan pendapat Poerwadarminta dalam (Melati, 2018) bahwa ketika kita berbicara kita perlu memiliki kata-kata yang tepat, lazim dan sesuai dengan kata umum.

Dalam rangka mendapatkan informasi yang lebih dalam, selanjutnya peneliti melakukan kegiatan observasi pada proses pembelajaran pragamtik edukasional. Dari pengamatan tersebut didapatkan data berupa tuturan mahasiswa yang menunjukkan bahwa Odilia Jayanti Mahu, Variasi Bahasa. $(68-80)$ 
penggunan unsur intralingual (kebahasaan) yang benar belum tampak dalam situasi pembelajaran. Misalnya mahasiswa menyebutkan kalimat "saya memberikan contoh seperti misalnya" merupakan bentuk penggunaan kalimat yang tidak efektif karena menurut Arifin (2009), salah satu ciri kalimat efektif adalah kehematan kata. Tuturan seperti "saya memberikan contoh seperti misalnya" merupakan salah satu bentuk pemggunaan kalimat tidak efektif karena dinilai mahasiswa menyebutkan istilah yang sama dalam satu kalimat membuat kalimat tersebut tidak efektif.

Pengumpulan informasi berikutnya yang dilakukan oleh peneliti adalah dengan mengadakan tes. Hasil dari kegiatan tes tersebut menunjukkan bahwa pemahaman mahassiwa secara teoritis mengenai konteks intralingual dan budaya bisa dikatakan sangat minim. Hal ini dibuktikan dengan skor jawaban dari 30 butir soal yang ada hanya 1 orang mahasiswa yang mencapai 24 benar selain itu hanya berkisar 11-19 benar. Kurangnya pemahaman mahasiswa mengenai konteks intralingual ini semakin memperkuat peneliti untuk mengembangkan buku ajar pragmatik edukasional terintegrasi konteks intralingual. Buku ajar ini tentunya sangat efektif karena sesuai dengan kebutuhan pengguna di lapangan, karena pertimbangan utama dari kegiatan pengembangan produk adalah efektivitas dan efisiensi (Sugiyono, 2015).

Mengenai pemaham tentang
konteks budaya pada mahasiswa
MPBSI. Peneliti menemukan fakta bahwa sebagian besar mahasiswa mengakui penerapan konteks budaya dalam pembelajaran sangat bagus untuk dilakukan. Hal ini dibuktikan dengan hasil jawaban kuesioner pernyataan 20 dan 31 yang mencapai 95\% dan 100\% mahasiswa menyetujui jika pembelajaran pragmatik edukasional dengan menerapkan konteks budaya akan membantu memahami maksud ketika berbicara dengan teman-teman yang berbeda latar budaya. Dari kegiatan observasi peneliti juga menemukan beberapa tuturan mahasiswa yang menunjukkan bahwa penerapan konteks budaya nyata hadir dalam pembelajaran. Seperti pada tuturan pada tabel 4.33 (TM 5). Pada penjelasan contoh yang disampaikan mahasiswa tersebut membuktikan bahwa perbedaan budaya berbahasa akan mengakibatkan tidak tersampainya isi komunikasi, selaras dengan yang disampaikan oleh (Zamzani, 2014), bahwa pada saat terjadi peristiwa komunikasi penutur bahasa Indonesia kerap menggunakan nilai kebudayaan penutur itu sendiri, sebagai akibatnya tidak jarang komunikasi tersebut kurang harmonis. Oleh karena itu, agar di antara mahasiswa MPBSI terjalin komunikasi yang baik maka perlu diberikan pemahaman mengenai penerapan konteks budaya dalam kegiatan berbahasa. Didukung oleh pendapat Zamzani agar interaksi antarpenutur yang berbeda latar budaya berjalan baik dan harmonis setiap orang khususnya peserta didik diperlukan pemahaman lintas budaya antara lain pemahaman sistem nilai berupa santun 
berkomunikasi, memiliki pandangan tentang suatu budaya, memahami tata makna kata dalam suatu budaya (Zamzani, 2014). Untuk mendukung pemahaman mahasiwa mengenai konteks intralingaul dan budaya dia atas dibutuhkan sumber bahan ajar. Namun, jawaban kuesioner (Pernyataan 38 dan 39) menunjukkan bahwa sumber buku ajar tentang konteks intralingual dan budaya tidak banyak ditemukan oleh mahasiswa. Kekurangan sumber bahan ajar ini tentu saja berpengaruh terhadap pemahaman mahasiswa tentang konteks intralingual dan budaya. Kebutuhan mahasiswa terhadap buku ajar pragmatik edukasional terintegrasi konteks intralingual dan budaya sangat mendasar.

Dalam rangka mencarikan informasi yang lebih akurat peneliti melakukan telaah dokumen (RPS) pragmatik edukasional. Dari hasil telaah dokumen itu peneliti menemukan bahwa belum adanya pengembangan materi secara mendalam dan terperinci mengenai konteks intralingual dan konteks budaya. Beberapa fenomena di atas semakin memperkuat alasan peneliti untuk mengembangkan buku ajar pragmatik edukasional terintegrasi konteks intralingualdan budaya.

Data-data yang terkait kebutuhan mahasiswa mengenai buku ajar pragmatik edukasional terintegrasi konteks intralingual dan budaya menjadi pegangan peneliti untuk mengembangkan buku ajar. Hal ini selaras dengan yang disampaikan oleh Prastowo bahwa untuk memilih bahan ajar haruslah sesuai dengan kebutuhan peserta didik baik dalam bentuk buku maupun tingkatan kesulitannya (Prastowo, 2015). Setelah mengetahui kebutuhan pembelajar, peneliti selanjutnya mencari dari berbagai sumber mengenai konteks intralingual dan budaya dan kemudian disusun di dalam buku ajar. Buku ajar pembelajaran pragamtik edukasional konteks intralingual dan budaya ini disajikan secara lengkap meliputi penggunaan sampul, halaman copyright, pengatur tata letak buku, kata pengantar, daftar isi, skema pemahaman, capaian dan indikator pembelajaran, penjelasan materi setiap bab, kegiatan, resume, latihan, rubrik penilaian, daftar pustaka,dan identitas penulis.

Kemudian, pada pemaparan materi buku ajar yang telah dibuat oleh peneliti memiliki 6 bab. Pada setiap bab memiliki capaian dan indikator pembelajaran. Tujuan pembuatan capaian pemeblajaran yaitu untuk mengetahui kemampuan yang diharapkan dari peserta didik setelah mempelajari materi dalam satu bab, dan tujuan pembuatan indikator pembelajaran sebagai acuan kriteria penilaian dalam menentukan kompeten atau tidaknya peserta didik (Prastowo, 2015).

Setelah capaian dan indikator pembelajaran terdapat skema pemahaman. Adapun tujuan pembuatan skema pemahaman yaitu untuk memberikan pemahaman kepada siswa dalam menguasai konsep materi atau topik yang dibelajarkan.

Selanjutnya, peneliti menyajikan materi setiap sub bab secara akurat dan 
lengkap.Penyajian materi setiap sub bab mengakomodasi materi bertipe pengetahuan faktual, pengetahuan konseptual, pengetahuan prosedural dan metakognitif. Tujuan pembuatan materi yang menggabungkan jenis pengetahuan faktual dan konseptual di dalam buku ajar yaitu agar mahasiswa mampu menghubungkan antara faktafakta yang terjadi di luar proses pembelajaran atau situasi nyata terkait penggunaan konteks intralingual dan budaya di dalam kelas dengan sistem ide yang lebih luas yang tersermin dalam pengetahuan seorang pakar disiplin ilmu tertentu (Anderson, 2010). Peneliti menemukan suatu pemikiran bahwa mahasiswa MPBSI Sanata Dharma sudah menerapkan penggunaan konteks intralingual dan budaya dalam setiap peristiwa berbahasa khususnya di dalam proses pembelajaran. Namun, yang menjadi masalah adalah mahasiswa sebagian besar tidak menyadari bahwa setiap mereka melakukan tindak tutur secara tersirat mereka sudah menerapkan penggunaan unsur intralingual. Oleh karena itu, dengan menyajikan pemikiran para pakar mengenai konteks intralingual dapat membantu mahasiswa untuk memahami bahwa nyatanya setiap satuan lingual yang mereka gunakan dalam peristiwa berbahasa merupakan salah satu penerapan penggunaan konteks intralingual dalam pragmatic edukasional.

Tujuan pembuatan materi bertipe pengetahuan prosedural agar mahasiswa memiliki kemampuan untuk menyelesaikan sesuatu. Sejalan dengan yang disampaikan Anderson bahwa pengetahuan prosedural yaitu pengetahuan tentang cara melakukan sesuatu (Anderson, 2010). Materi bertipe pengetahuan prosedural ini tampak dalam pembuatan kegiatan dan tugas. Pada kegiatan pembelajaran mahasiswa diminta untuk melakukan observasi, menemukan data, menganalisis hasil temuan dan mempresentasikan kembali hasil temuan itu di depan kelas. Materi bertipe pengetahuan metakognitif tampak pada kegiatan dan tugas yang dikerjakan oleh mahasiswa. Melalui kegiatan dan tugas yang diberikan dapat membantu merekauntuk semakin mengenal diri sendiri, gaya belajar, proses berpikir yang dapat meningkatkan hasil belajar. Sejalan dengan yang disampaikan oleh Anderson bahwa pengetahuan metakognitif adalah penegratahuan tentang kognisi secara umum dan kesadaran akan pengetahuan tentang kognisi sendiri serta membuat mahasiswa makin menyadari serta bertanggung jawab atas pemikiran mereka.Penyajian materi buku ajar juga menggunakan contoh percakapan yang kontekstual agar pembelajaran bahasa bertumpu pada kemampuan pembelajar dalam menggunkan bahasa sebagai fungsi komunikasi. Pada buku ajar juga memuat rubrik penilaian. Adapun tujuan pembuatan rubrik penilaian yaitu untuk memperoleh informasi secara objektif, berkelanjutan, dam menyeluruh tentang proses dan hasil belajar peserta didik (Dekdiknas, 2001). 


\section{SIMPULAN}

Berdasarkan hasil penelitian didapatkan informasi, yaitu 1) mahasiswa MPBSI belum memahami baik secara teoritis mapun penerapan penggunaan unsur intralingual yang benar dalam peristiwa berbahasa 2) mahasiswa MPBSI menyetujui bahwa pembelajaran pragmatik edukasional dengan penerapan konteks budaya akan membantu memahami maksud komunikasi lawan tutur yang berbeda latar budaya, 3) mahasiswa membutuhkan buku ajar yang di dalamnya terdapat pemapan materi mengenai konteks intralingual dan budaya. Berdasarkan hasil penelitian tersebut dikembangkan buku ajar yang di dalamnya terdapat pemaparan materi mengenai konteks intralingual dan budaya. Hasil pengembangan buku ajar tersebut menunjukkan bahwa buku ajar pembelajaran pragmatik edukasional konteks intralingual dan budaya layak digunakan pada mahasiswa Program Magister Pendidikan Bahasa dan Sastra Indonesia Universitas Sanata Dharma. Penlaian kelayakan buku ajar tersebut didapatkan dari hasil validasi aspek materi, bahasa dan tampilan yang telah dilakukan oleh ahli, penilian buku ajar yang telah dilakukan oleh dosen mata kuliah pragmatik edukasional, serta uji coba lapangan kepada mahasiswa program magister pendidikan bahasa dan sastra Indonesia. Berdasarkan hasil validasi ahli terhadap aspek materi mencapai skor 3,20 dengan kategori "baik", aspek kebahasaan mencapai skor 4 dengan kategori "sangat baik", aspek tampilan mencapai skor 3,6 dengan kategori "baik", secara keseluruhan mendapatkan skor ratarata 3,6 dengan kategori "baik". Selanjutnya berdasarkan hasil penilaian dosen mata kuliah pragmatik edukasional. penilaian pada aspek materi mendapatkan skor 4 dengan katgori "sangat baik", penilaian aspek kebahasaan mendapatkan skor 4 dengan kategori "sangat baik" dan pada penilaian aspek tampilan mendapatkan skor 3,8 dengan kategori "sangat baik". Jumlah keseluruhan kulitas buku ajar yang dinilai oleh dosen mata kuliah adalah 3,93 dengan kategori "sangat baik". Berdasarkan hasil uji coba lapangan, penilaian mahasiswa terhadap kualitas buku ajar aspek materi mendapatkan skor 3,55 dengan kategori "sangat baik ", aspek kebahasaan mendapatkan skor 3,56 dengan kategori "sangat baik", aspek tampilan mendapatkan skor 3,45 dengan kategori "sangat baik".

Rangkuman skor rata-rata penilaian kulitas buku ajar dari mahasiswa adalah 3,56 dengan kategori "sangat baik". Berdasarkan uji efektivitas, dapat disimpulkan bahwa buku ajar yang dikembangkan oleh peneliti dapat digunakan mahasiswa dalam proses pembelajaran pragmatik edukasional, hal ini dapat dilihat dari hasil pengerjaan tugas dari mahasiswa yang sudah menjelaskan secara rinci dan lengkap mengenai pengertian konteks intralingual, jenis-jenis unsur konteks intralingual atau koteks dalam wacana, hubungan koteks dan konteks, peran kohesi dan koherensi sebagai penanda unsur intralingual dalam 
sebuah wacana. Hal yang sama pada tugas tentang konteks budaya, hasil pengerjaan mahasiswa juga menunjukkan bahwa buku ajar sangat efektif untuk digunakana. Hal ini dapat dibuktikan melaui hasil jawaban mahasiswa yang menjelaskan secara lengkap dan terperinci pengertian dari konteks budaya, konteks budaya dalam kaitannya dengan kehidupan manusia dan relevansinya dengan pembelajaran, peran konteks budaya dalam pembelajaran pragmatik edukasional, maanfaat penerapan konteks budaya dalam pembelajaran.

\section{DAFTAR PUSTAKA}

Anderson, L.W dan Krathwohl. D.R. 2010. Kerangka Landasan untuk Pembelajaran, Pengajaran, Pengajaran dan Asesmen (Revisi Taksonomi Pendidikan Bloom). Yogyakarta: Pustaka Pelajar.

Arifin, Z dan Juniayah. 2009. Sintaksis. Jakarta: PT Grasindo.

Izhar. 2016. Mengidentifikasi Cara Berpikir Deduktif Dan Induktif Dalam Teks Bacaan Melalui Pengetahuan Koteks Dan Referensi Pragmatik. Jurnal Pesona, (online) Vol 2 (1) 63-73.

Tersedia: file:/ / C:/Users/acer/Downloa ds/141-361-1-PB.pdf. (19 Januari 2018).

Kridalaksana, Harimurti. 2011. Kamus Linguistik. Jakarta: Gramedia Pustaka.
Melati, S. (2015). Penggunaan Unsur Intralingual dan Ekstralingual Dalam Daya Bahasa danNilai Rasa Bahasa Pada Acara Sentilan Sentilun Metro TV Periode Agustus dan September 2014 Sebagai Penanda Kesantunan Berkomunikasi. Skripsi. (online)Yogyakarta: Universitas Sanata Dharma. Tersedia https:/ / repository.usd.ac.id/583 /2/111224066_full.pdf September 2017).

Prastowo, A. 2015. Panduan Kreatif Membuat Bahan Ajar Inovatif. Yogyakarta: Diva Press

Sriyanto. 2017. Koteks Dalam Wacana Politik Jawa Pos Edisi Mei 2016. BASTRA, (Online) Vol 4 (1). Tersedia:

(http://appibastra.or.id/ojs/ind ex.php).

Sugiyono. 2015. Metode Penelitian Pendidikan Pendekatan Kuantitaif, Kualitatif, dan RED. Bandung: Alfabeta.

Sugiyono. 2017. Metode Penelitian dan Pengembangan. Bandung: Alfabeta

Tegeh, I Made., Dkk. 2014. Model Penelitian Pengembangan. Yogyakarta: Graha Ilmu.

Widoyoko, E.P. 2015. Teknik Penyusunan Instrumen Penelitian. Yogyakarta: Pustaka Pelajar.

Zamzani. 2007. Kajian Sosiopragmatik. Yogyakarta: Citpa Pustaka. 